\title{
Production of Value-Added Bioproducts Using a Modified Continuous Biofilm Reactor by Citrobacter Freundii DSM 15979
}

\section{Mine Gungormusler (D)}

Izmir University of Economics, Department of Bioengineering, Izmir, Turkey

Izmir University of Economics, Department of Genetics and Bioengineering, Izmir, Turkey

\section{ABSTRACT}

he present paper reports the ability of Citrobacter freundii, strain DSM 15979, to 1 produce value-added chemicals from biodiesel derived glycerol in a mesophilic modified continuous biofilm reactor operating under mesophilic continuous conditions at a specified hydraulic retention time (HRT). Increasing initial glycerol concentrations $\left(G_{\text {in }}\right)$ $(10$ to $144 \mathrm{~g} / \mathrm{L})$ were tested in order to evaluate their effects on simultaneous production of value-added products with immobilized whole cells. Initial glycerol concentration was found to be a significant independent variable for the productions of 1,3-PDO, 2,3-BD, ethanol, acetic, succinic and lactic acids under different organic loading rates (OLR). The major end-products in the metabolic pathway were found to be 1,3-PDO and 2,3-BD. They reached maximum values of $26.1 \mathrm{~g} / \mathrm{L}$ and $18.8 \mathrm{~g} / \mathrm{L}$ at $92 \mathrm{~g} / \mathrm{L}$ of initial crude glycerol feeding, which represents an OLR of $11.5 \mathrm{~g} / \mathrm{L}$.h. These results suggest that the formation of biofilms were beneficial for the utilization of high substrate concentrations, thus, the employment of immobilized cells of C. freundii DSM 15979 in a modified continuous biofilms reactor is favorable for mixed glycerol fermentations.

Keywords: Glycerol fermentation, Biofilm, Citrobacter freundii

\author{
Article History: \\ Received: 2020/12/30 \\ Accepted: 2021/02/24 \\ Online: $2021 / 03 / 31$
}

Correspondence to: Mine Güngörmüsler, E-mail: mine.gungormusler@ieu.edu.tr; Phone: +902324888392

\section{INTRODUCTION}

Commodity chemicals are derived largely from raw materials based on fossil resources. The environmentally friendly biotechnological approaches potentially form same or functionally similar chemicals from sustainable materials. In addition, their effects on reduction in greenhouse gas emissions provide an additional advantage. Various industrial byproducts and domestic waste materials can be used as raw materials to convert into value-added chemicals by means of fermentative pathways. Numerous studies reported the technical viability of valorization of biodiesel driven glycerol into 1,3-PDO, 2,3-BD, ethanol, butanol, $\mathrm{H} 2$, acetic acid, lactic acid and other organic acids (Fig. 1). The versatility of the final byproduct of this conversion is due to the utilization of different metabolic pathways by numerous species including Klebsiella pneumoniae [1], Citrobacter freundii [2-6], Pantoea agglomerans [7], Entrobacter aerogenes [8], Lactobacillus brevis [9], Lactobacillus diolivorans [10], Lactobacillus reuteri [11], Clostridium butyricum [12], Clostridium perfringens [13], Clostridium acetobutylicum [14], Clostridium paste- urianum [15], and Clostridium beijerinckii [16]. The major end-products from the glycerol fermentation can be integrated to a wide variety of applications such as 1,3-PDO in the manufacturing of polyesters, polyethers, polyurethanes, polytrimethylene-terephthalate, textiles, carpets and plastics [17]; 2,3-BD in the manufacturing of printing inks, jet fuels, explosives, perfumes, foods, pharmaceuticals, and plasticizers [18], and acetic acid mainly as a solvent [19]. The beneficial properties of these chemicals characterize them as special commodity chemicals attributing important roles in industrial processes.

Glycerol can be metabolized by two main reactions including one reductive branch in which at first it is dehydrated to 3-hydroxypropionaldehyde and water, it is then reduced to 1,3-PDO under the utilization of the reducing power nicotinamide adenine dinucleotide (NADH) and an oxidative branch where the required reducing power is formed resulting in the formation of metabolites demonstrated in Fig. 1 [2, 20]. 


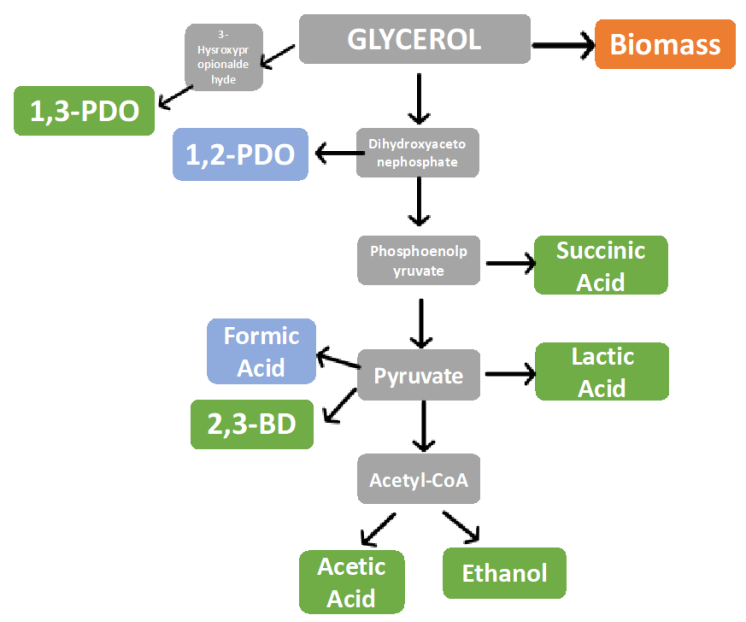

Figure 1. Main metabolites produced in the glycerol degradation pathways of Enterobacteriaceae, adapted from [2].

Several strategies have been employed for glycerol conversion with high yields of bioproducts [20] such as optimization of the fermentation medium [21] and operational parameters [22], employing different reactor configurations, applying fed-batch productions [23] to prevent the inhibitions of high initial substrate concentrations and endproducts, and metabolic engineering [24]. Apart from these, one of the main approaches include increasing the final product concentrations with the help of high cell densities [25]. In this regard, immobilization is the key mode of action to enhance productivities. During this process microorganisms form biofilms without the involvement of chemicals and thick layers of cells are generated by either on attaching to materials or naturally on surfaces or they are entrapped [26]. In a study by Paranhos and Silva [27] a continuous anaerobic fluidized bed reactor (AFBR) was used to optimize the productions of $\mathrm{H} 2,1,3-\mathrm{PDO}$ and propionic acid from crude glycerol with the formation of biofilms of mixed cultures indicating the effectiveness of immobilization on productivities [27]. Another report on the production similarly by the utilization of an anaerobic sludge also reported the ability of the microorganisms to stabilize under elevating OLR ( 25 to $62.5 \mathrm{~g} / \mathrm{L} . \mathrm{d})$ with the help of granulation of cells [28].

As reported previously, several strains and isolates of C. freundii have been studied in the literature with different parameters. Whereas, the fluidized bed biofilm reactor was used for the first time in the literature with increasing crude glycerol concentrations in a chemostat providing the novelty of the work. The aim of the study was to investigate the effectiveness of the utilization of a modified fluidized bed biofilm reactor (MCBR) to produce value-added biochemicals from crude glycerol by C. freundii DSM 15979. Accordingly, the effects of glycerol concentration feed on the crude glycerol driven productions of 1,3-PDO, 2,3-BD, lactic and acetic acids and the influence of the OLR in the MCBR by C. freundii DSM 15979 was comparatively studied for the first time in the literature. The results of the present study reports the advantages of the formation of biofilms to enhance the yields of final products at increasing OLRs.

\section{MATERIAL AND METHODS}

\section{Experimental Set-up and Biofilm Reactor Conditions}

A Pyrex ${ }^{\oplus}$ glass bioreactor (Corning Inc., USA) was employed for the fluidized bed biofilm reactor studies. The bioreactor had the following specifications: $15 \mathrm{~cm}$ height with an i.d. of $10 \mathrm{~cm}$ and 8 outlets for feed and gas connections. The total volume and working volume of the of the bioreactor were $1000 \mathrm{~mL}$ and $320 \mathrm{~mL}$, respectively. Ceramic supports were added to the bioreactor as the immobilization material. The ceramic supports were decontaminated by distilled water followed by an overnight drying procedure at $105^{\circ} \mathrm{C}$, prior to application.

The temperature in the bioreactor was kept at $30^{\circ} \mathrm{C}$ using a hot plate magnetic stirrer (MR Hei-Standard, Heidolph, Germany) and monitored by an external thermal probe (EKT Hei-Con, Heidolph, Germany). One peristaltic pump for inlet feeding and one peristaltic pump for effluent collection were employed during production (WM 400, Watson Marlow Fluid Technology Group, USA). The pump was calibrated using silicon tubing and distilled water using a mass based method. 10 different levels and 2 different directions in the pump were measured twice (60 to 120 seconds) with distilled water. Accordingly, mass of each level was recorded to calculate the calibration coefficient of the pump in regards to the set level. $\mathrm{pH}$ was monitored at each sampling point, and accordingly, adjusted to 6.5 to 7.0 with the manual addition of $\mathrm{NaOH}(2 \mathrm{M})$ when necessary during fermentation. Samples were taken from the effluent to be analyzed for residual glycerol, 2,3-BD, ethanol, 1,3-PDO, acetic, lactic and succinic acids.

\section{Substrate Preparation and Application}

The substrate used in this study was crude glycerol obtained from biodiesel production from a factory in Torbalı (Izmir, Turkey) in $10 \mathrm{~L}$ plastic containers. The composition of crude glycerol used was provided from the company as $54.35 \%$ glycerol (w/v), 34.81\% water, $6.52 \%$ fat and ester, $<1 \%$ methanol (ppm), 3.53\% $\mathrm{NaOH}$, and $0.64 \% \mathrm{NaCl}$.

Glycerol determination in biodiesel waste was done by High Pressure Liquid Chromatography (HPLC). It was found to be $50 \%(\mathrm{w} / \mathrm{v})$, the rest of the content were soap, trace amount of mixed salts and caustic. The initial content of glycerol in biodiesel waste was $80 \%$. This amount was diluted using distilled water for a final concentration of 50\% (500 $\mathrm{g} / \mathrm{L}$ ) in order to keep the waste product liquified. The above mentioned solution was diluted to required concentration during fermentation. The fermentation medium was prepa- 
red as $5.72 \mathrm{~g} \mathrm{~K}_{2} \mathrm{HPO}_{4}, 1.5 \mathrm{~g} \mathrm{KH}_{2} \mathrm{PO}_{4}, 2.0 \mathrm{~g}\left(\mathrm{NH}_{4}\right)_{2} \mathrm{SO}_{4}, 1.0 \mathrm{~g}$ yeast extract, $0.24 \mathrm{~g} \mathrm{MgSO} \cdot 7 \mathrm{H}_{2} \mathrm{O}, 0.5 \mathrm{~mL} \mathrm{FeSO}_{4} \cdot 7 \mathrm{H}_{2} \mathrm{O}$ solution and $1.0 \mathrm{~mL}$ trace element solution. The trace element solution consisted of (mg/L distilled water) $200 \mathrm{CoCl}_{2} \cdot 2 \mathrm{H}_{2} \mathrm{O}$, $100 \mathrm{MnCl}_{2} \cdot 4 \mathrm{H}_{2} \mathrm{O}, 70 \mathrm{ZnCl}_{2}, 60 \mathrm{H}_{3} \mathrm{BO}_{3}, 20 \mathrm{CuCl}_{2} \cdot 2 \mathrm{H}_{2} \mathrm{O}, 35$ $\mathrm{Na}_{2} \mathrm{MoO}_{4} \cdot 2 \mathrm{H}_{2} \mathrm{O}, 25 \mathrm{NiCl}_{2} \cdot 6 \mathrm{H}_{2} \mathrm{O}$, and $0.9 \mathrm{ml} \mathrm{HCl}(37 \%)$.

The MCBR was fed with crude glycerol at the concentration determined previously by [7] for a concentration of between 11 to $144 \mathrm{~g} / \mathrm{L}$. The substrate was fed in incrementing concentrations as follows, initial glycerol concentrations of $\left(G_{i n}\right) ; 11,23,48,72,92,109,112,144 \mathrm{~g} / \mathrm{L}$ of crude glycerol corresponding to organic loading rates (OLR) of 1.4, 2.9, 6.0, 9.0, 11.5, 13.6, 14.0 and $18.0 \mathrm{~g} / \mathrm{L} . \mathrm{h}$.

\section{Inoculum Preparation and Biofilm Formation}

The inoculum used in this study was Citrobacter freundii, strain DSM 15979. The microorganism was provided by Alma Mater Studiorum University in Bologna from the German Collection of Microorganisms and Cell Cultures (DSMZ). The microorganisms were sub-cultured from agar cultures in Tryptic Soy Broth (TSB) that was used as growth medium, to be activated. They were then incubated at $30^{\circ} \mathrm{C}$ during at least $10 \mathrm{~h}$.

Prior to incubation and fermentation, the bioreactor filled with immobilization materials was autoclaved $\left(121^{\circ} \mathrm{C}\right.$ at $1 \mathrm{~atm}$ for $30 \mathrm{~min}$ ) for sterilization. The reactor was allowed to cool down and then inoculated with a stock culture of C. freundii DSM 15979 (10\% (v/v)) together with sterile fermentation medium. The bioreactor was washed with $\mathrm{N}_{2}$ to maintain anaerobic conditions. The bacteria was inoculated to the immobilized bioreactor under sterile conditions for 3 days with a dilution rate of $0.04 \mathrm{~h}^{-1}$ using a peristaltic pump (Watson Marlow 400). The continuous fermentation was initialized at the $72^{\text {th }} \mathrm{h}$ of the fermentation following a visible formation of the biofilm on the immobilization material as shown in Fig. 2. Glycerol concentration, thus OLR, in the fermentation medium was changed after at least 6 cycles (= every 2 days) maintaining a hydraulic retention

\section{$0^{\text {th }} \mathbf{h}$ \\ Bioreactor setup}
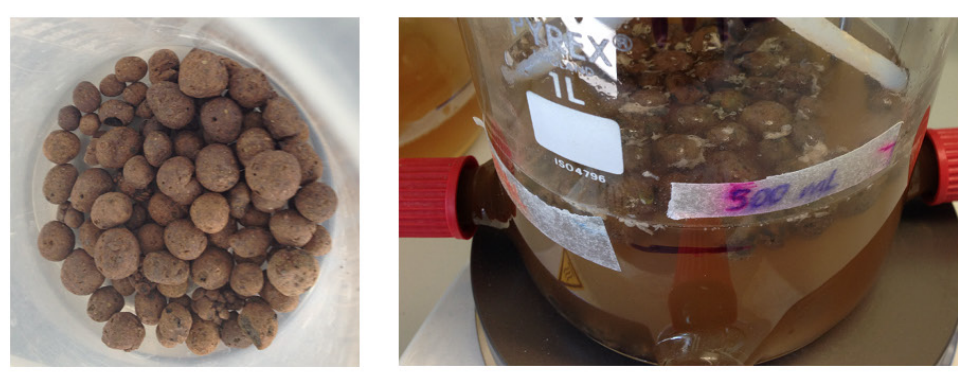

$48^{\text {th }} \mathrm{h}$

\section{Biofilm formation}

fermentation $\left(72^{\text {th }} h\right)$. time (HRT) of $8 \mathrm{~h}$ (Dilution rate: 0.125 1/h). The reported results belong to the final three obtained values for each OLR, thus, the analysis were performed in triplicates and the measurements were reported as mean values with standard deviations.

\section{Sampling and Analysis}

$10 \mathrm{~mL}$ of samples were collected from the bioreactor at each sampling point and $1.5 \mathrm{~mL}$ of the sample was centrifuged at $7379 \mathrm{x}$ g for $15 \mathrm{~min}$ to be analyzed using a microcentrifuge (Beckman Coulter ${ }^{\mathrm{TM}}$ Microfuge $^{\circledR} 18$ Centri- $^{-}$ fuge with $24 \times 0.22 \mathrm{~L}$ angle rotor). The supernatant was filtered through $0.22 \mu \mathrm{m}$ syringe filters. Glycerol as the substrate, and 1,3-PDO, 2,3-BD, lactic acid, acetic acid, succinic acid and ethanol as the products were measured using HPLC (Agilent, USA) with a Phenomenex Rezex RHM Monosaccharide (H+) $300 \times 7.8 \mathrm{~mm}$ ion exchange column, using a Thermo Surveyor Refractive Index Detector. The column temperature was $65^{\circ} \mathrm{C}$ and the detector temperature was $40^{\circ} \mathrm{C}$ and the injection volume is 20 $\mu \mathrm{L}$. A solution of $5 \mathrm{mM} \mathrm{H}_{2} \mathrm{SO}_{4}$ was used as mobile phase at a flow rate of $0.6 \mathrm{~mL} / \mathrm{min}$ [29].

Phosphate buffer solution ( $\mathrm{pH}$ 7.1) was used to rinse the immobilization materials at the end of fermentation in order to remove the attached microorganisms from the surface of the materials. An additional 10 min sonication was employed in order to further remove remaining biomass on the surfaces followed by a final washing with the phosphate buffer solution was applied to calculate the immobilized to suspended cells percentile. The gravimetric method was used for total suspended solids (TSS) measurements [30]. Filter papers with a diameter of $0.45 \mu \mathrm{m}$ were dried in an oven for $24 \mathrm{~h}$ at $105^{\circ} \mathrm{C}$. Following, they were placed into a desiccator to cool to room temperature and filter papers were weighed to record their tares that were used for calculation. After that, the sample that was nearly $5 \mathrm{~mL}$ were filtered by the filter paper in the Erlenmeyer flask. The filtered paper was placed into an oven for $24 \mathrm{~h}$ at $105^{\circ} \mathrm{C}$. Then, they were transferred to the desiccator and left to cool down for 30 min and weighed. All results of weighing were calculated $72^{\text {th }} \mathrm{h}$ Fermentation initiated

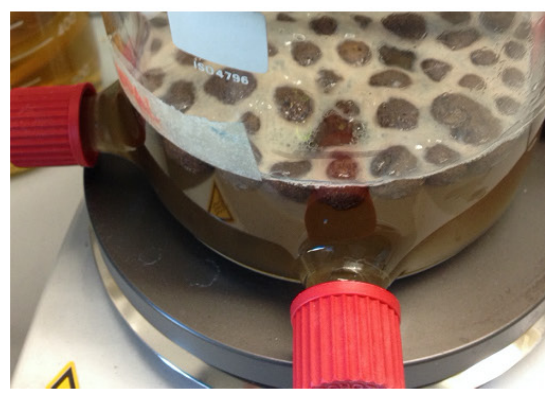


according to the Equation (1) [30]:

$$
\begin{aligned}
& T_{S S}(m g / L)=\left(\begin{array}{l}
\text { Final weigh of filter paper }(g) \\
\text {-Tare of filter paper }(g)
\end{array}\right) \text { (1) } \\
& x 1000000 / \text { Volume of sample }
\end{aligned}
$$

\section{Calculations}

Equation 2 was used to calculate the yields for the end product concentrations, and Equation 3 was used to calculate the productivities of the end products [31].

$$
Y=C_{x} / S_{i}
$$

$$
Q=C_{x} /\left(t_{f}-t_{i}\right)
$$
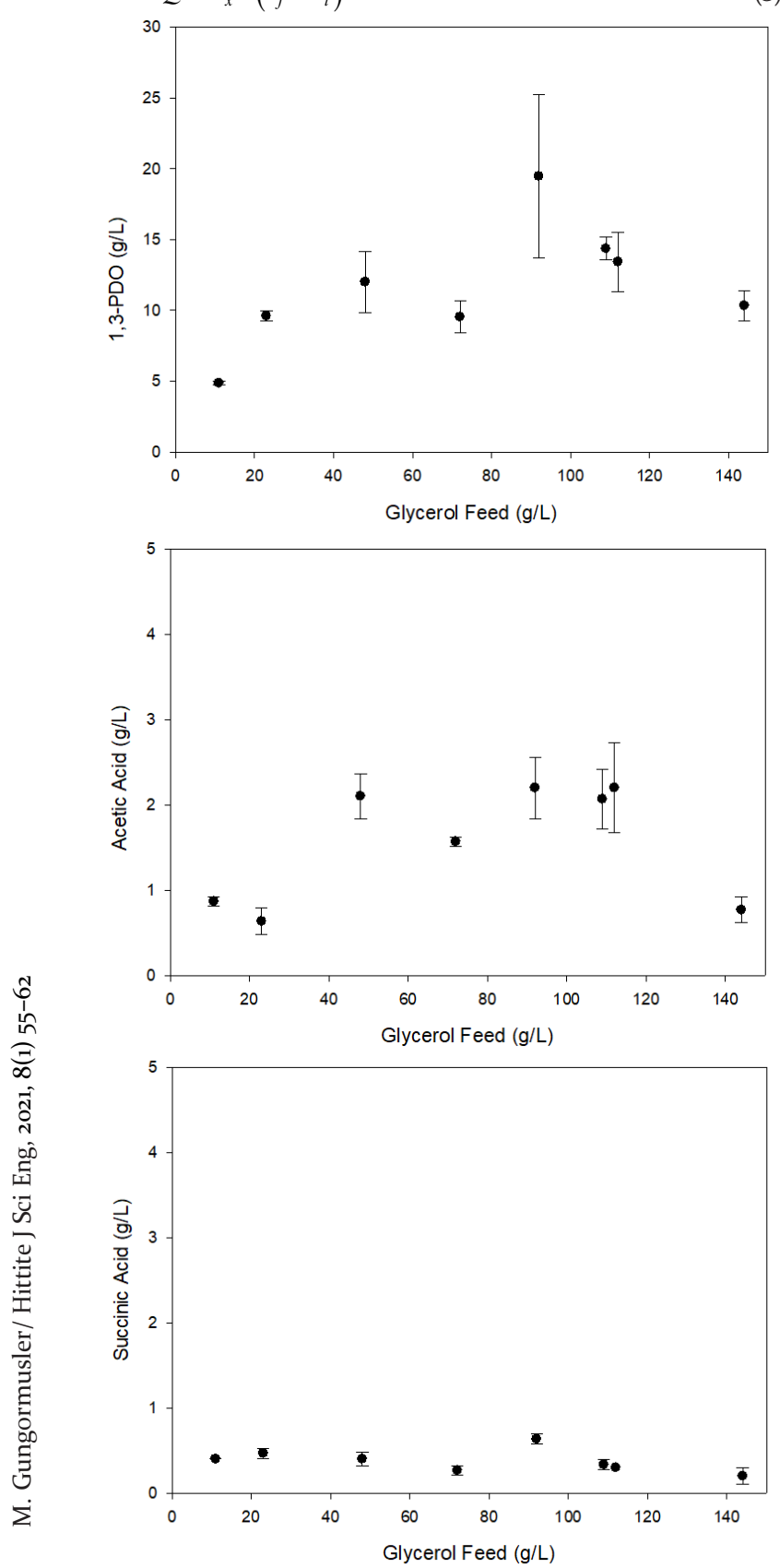

Where;

Y: the end product yield ( $\mathrm{mol}_{\text {end product }} / \mathrm{mol}_{\text {consumedglycerol }}$ ); $\mathrm{C}_{\mathrm{x}}$ : the compound concentration $(\mathrm{g} / \mathrm{L}) ; \mathrm{S}_{\mathrm{i}}$ : the initial substrate concentration $(\mathrm{g} / \mathrm{L})$; $\mathrm{Q}$ : the productivity $(\mathrm{g} / \mathrm{L} . \mathrm{h})$; $\mathrm{t}_{\mathrm{f}}$ : the final fermentation time (h); $t_{i}$ : the hydraulic retention time (h).

\section{Statistical analysis}

All data obtained from the MCBR were compared with a Kruskal-Wallis one-way analysis of variance (ANOVA) on ranks (Sigma Plot, USA). The results were evaluated with a $95 \%$ confidence interval.
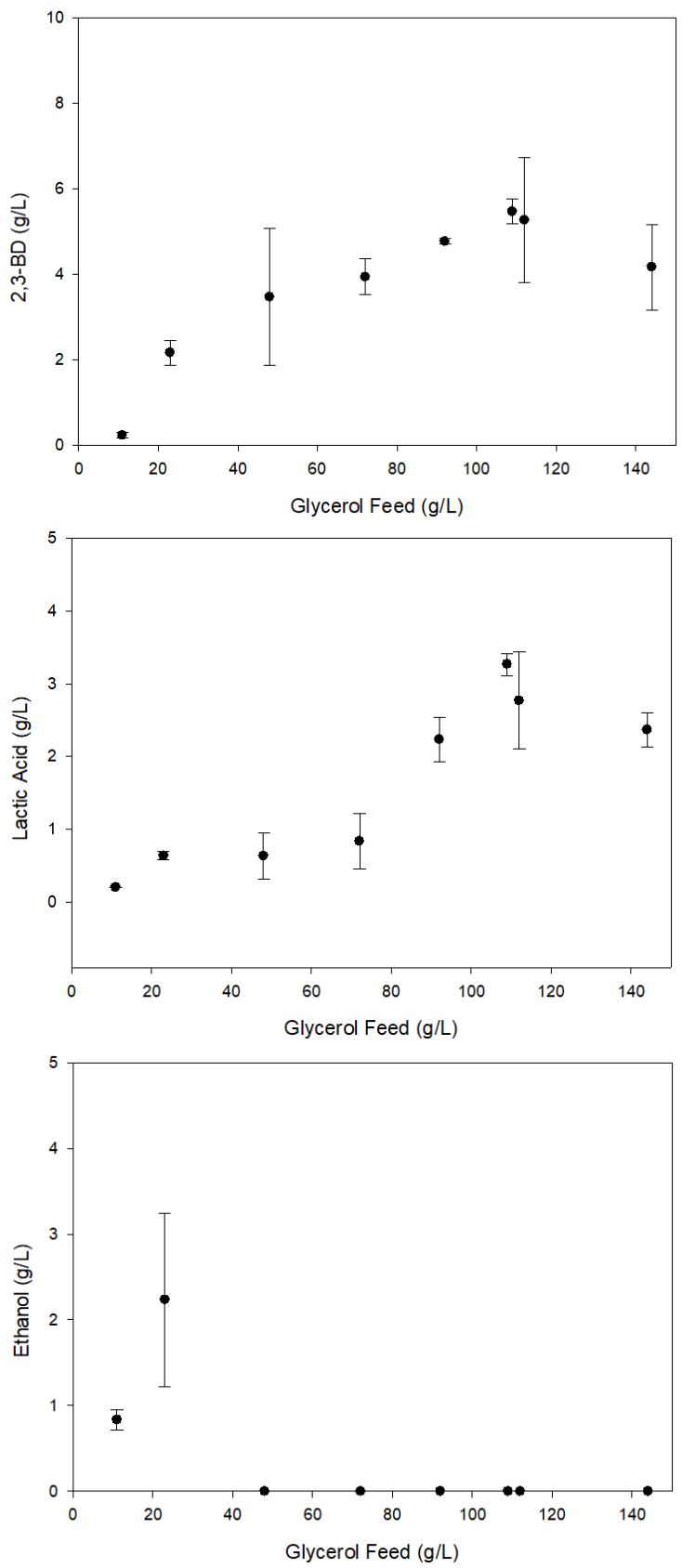

Figure 3. By-product concentrations at elevating glycerol feed (11 to $144 \mathrm{~g} / \mathrm{L}$ ). 


\section{RESULTS AND DISCUSSION}

The biofilm reactor employed in the current study resulted in several by-products including organic acids, 1,3PDO, and 2,3-BD. As depicted in Fig. 3, the final product with the highest concentration was 1,3-PDO reaching a maximum value of $26.1 \mathrm{~g} / \mathrm{L}$ at an OLR of $11.5 \mathrm{~g} / \mathrm{L} . \mathrm{h}$. 2,3-BD reached the second highest concentration followed by lactic acid, ethanol, acetic acid, and succinic acid; the highest concentrations were reported as 18.8, 3.5, 3.4, 3.0, and $0.8 \mathrm{~g} / \mathrm{L}$, respectively. Throughout the study the highest ethanol yield was reported to reach $0.2 \mathrm{~mol} / \mathrm{mol}$. However, when the glycerol feed was increased over 48 g/L, no ethanol production was observed. Similarly, according to Vivek et al. (2017), when the initial glycerol concentration was increased up to $60 \mathrm{~g} / \mathrm{L}$, no ethanol was reported [9].

In the present study, increased OLR negatively affected glycerol utilization (Table 1). The consumption rate was inversely proportional to the increasing OLR values except for the slight remission at $6.0 \mathrm{~g} / \mathrm{L}$.h. This situation can be explained by the acclimatation of the microorganisms following 6 cycles of the same condition, due to a sharp increase in the substrate concentration by $108 \%$. Previous reports in the literature stated the inhibitory effects of high concentrations of the substrate on wild type microorganisms [20]. In order to overcome this issue and enhance the titers of 1,3-PDO and other metabolites, strategies such as acclimation of the microorganisms with the formation of biofilms [32], immobilization on inert materials, entrapment of cells in gels [33] or fed-batch mode of processing have been employed [5, 34, 35]. Similarly to the reported literature, at least 6 cycles of OLR was also successfully applied to the biofilm of C. freundii DSM 15979 cells in the present study to enhance the productivities (Table 1). The represented calculations were average of triplicate data during the experiments. ANOVA on ranks (Sigma Plot, USA) showed that there was a statistically significant difference in molar yields of the products based

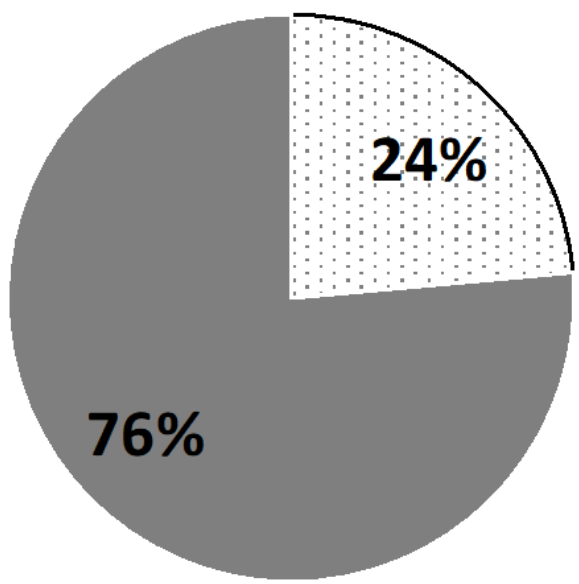

Figure 4. Immobilized (solid colored) vs suspended (dot illustrated) cell ratios as calculated at the end of the study.

on the elevating initial glycerol concentrations $(p<0.05)$. Aquino de Souza et al. (2014) reported that the entrapped cells of K. pneumoniae BLh-1 reached the maximum productions of 1,3-PDO, 2,3-BD and ethanol by $22.22 \mathrm{~g} / \mathrm{L}, 9.98$ $\mathrm{g} / \mathrm{L}$ and $1.42 \mathrm{~g} / \mathrm{L}$, respectively when $65 \mathrm{~g} / \mathrm{L}$ of crude glycerol was fed to the system. In the present study, C. freundii DSM 15979 reported the maximum 1,3-PDO production when 92 $\mathrm{g} / \mathrm{L}$ of crude glycerol was fed to the biofilm reactor together with the highest 2,3-BD titer (18.8 g/L), however, glycerol concentrations higher than $23 \mathrm{~g} / \mathrm{L}$ resulted in no production of ethanol (Fig. 3). As shown in Fig. 4, the results of the TSS measurements also proved that $76 \%$ of the microorganisms were successfully immobilized on the ceramic immobilization material in the form of a biofilm.

A previous study by the research group reported the production of various metabolites from crude glycerol by suspended systems [7]. Accordingly, glycerol consumption by C. freundii DSM 15979 was reported to be sharply declined (as low as 4\% consumption at Gin $140 \mathrm{~g} / \mathrm{L}$ ) with high glycerol loading as opposed to immobilized cultures reported in the present study. These results indicate the improved resistance of whole cells with the formation of biofilms.

\begin{tabular}{|c|c|c|c|c|c|c|c|c|c|c|c|}
\hline $\begin{array}{c}\text { Monitoring } \\
\text { Time } \\
\text { (h) }\end{array}$ & $\begin{array}{c}\text { Glycerolinitial } \\
(g / L)\end{array}$ & $\begin{array}{c}O L R \\
(g / L . h)\end{array}$ & $\begin{array}{c}\text { Glycerol } \\
\text { Removal } \\
(\%)\end{array}$ & $Y_{1,3}-P D O$ & $Y_{2,3}-B D$ & $Y_{\text {lactic }}$ acid & $Y_{\text {aetic }}$ acid & $Y_{\text {succinic }}$ acid & $Y_{\text {ethanol }}$ & $Q_{1,3}-P D O$ & $p H$ \\
\hline 72 & 11 & 1.4 & 100 & $0.54 \pm 0.01$ & $0.02 \pm 0.01$ & $0.02 \pm 0.00$ & $0.12 \pm 0.01$ & $0.03 \pm 0.00$ & $0.15 \pm 0.02$ & $0.60 \pm 0.00$ & $6.28 \pm 0.35$ \\
\hline 120 & 23 & 2.9 & 99 & $0.51 \pm 0.02$ & $0.10 \pm 0.01$ & $0.03 \pm 0.00$ & $0.04 \pm 0.01$ & $0.02 \pm 0.00$ & $0.20 \pm 0.09$ & $1.17 \pm 0.06$ & $6.43 \pm 0.43$ \\
\hline 168 & 48 & 6.0 & 51 & $0.78 \pm 0.27$ & $0.23 \pm 0.23$ & $0.03 \pm 0.02$ & $0.17 \pm 0.09$ & $0.02 \pm 0.01$ & 0 & $1.27 \pm 0.55$ & $6.37 \pm 0.15$ \\
\hline 216 & 72 & 9.0 & 69 & $0.18 \pm 0.02$ & $0.16 \pm 0.05$ & $0.0 \pm 0.06$ & $0.0 \pm 0.08$ & $0.0 \pm 0.01$ & 0 & $1.17 \pm 0.12$ & $6.54 \pm 0.07$ \\
\hline 264 & 92 & 11.5 & 70 & $0.56 \pm 0.28$ & $0.31 \pm 0.10$ & $0.14 \pm 0.05$ & $0.22 \pm 0.10$ & $0.03 \pm 0.01$ & 0 & $2.47 \pm 0.72$ & $6.01 \pm 0.17$ \\
\hline 288 & 109 & 13.6 & 64 & $0.25 \pm 0.02$ & $0.08 \pm 0.01$ & $0.05 \pm 0.22$ & $0.05 \pm 0.01$ & 0 & 0 & $1.80 \pm 0.10$ & $6.18 \pm 0.16$ \\
\hline 384 & 112 & 14.0 & 42 & $0.42 \pm 0.22$ & $0.14 \pm 0.08$ & $0.07 \pm 0.04$ & $0.10 \pm 0.07$ & $0.01 \pm 0.00$ & 0 & $1.70 \pm 0.26$ & $6.56 \pm 0.47$ \\
\hline 432 & 144 & 18.0 & 20 & $0.44 \pm 0.09$ & $0.15 \pm 0.02$ & $0.09 \pm 0.02$ & $0.04 \pm 0.01$ & $0.01 \pm 0.00$ & 0 & $1.30 \pm 0.10$ & $6.27 \pm 0.16$ \\
\hline
\end{tabular}




\section{Comparison of 1,3-PDO, 2,3-BD and organic acid production}

The 1,3-PDO and 2,3-BD molar yields achieved in this study are the maximum ones obtained via crude glycerol fermentation compared to the other reported studies by wild type C. freundii strains that formed biofilms (Table 2 ). The literature reports depicted the feasibility of the valorization of crude glycerol by various strains reaching up to $170 \mathrm{~g} / \mathrm{L}$ of feed $[3,5]$.

As shown in Table 1, as the initial substrate concentration was increased, the consumption of glycerol was declined also causing a decrease in the productions of end-products suggesting an exertion of inhibition. A similar case was reported by Metsoviti et al. [5]. The group employed a fedbatch strategy in order to prevent this issue. Accordingly, they successfully improved the yields reaching a maximum 1,3-PDO concentration of $68.1 \mathrm{~g} / \mathrm{L}$.

Previous studies has suggested that under conditions where the energy is sufficient, microorganisms prefer the production pathways of products that are less toxic and that energy needs do not direct metabolism [36]. Accordingly, as also reported in Fig. 1, amongst all intermediate and end-products of glycerol fermentation, lactic acid, ethanol, butanol and $\mathrm{H} 2$ are the most important competitors of 1,3$\mathrm{PDO}$ due to the requirement of reduced NADH during their production. Lower concentrations of these products are desired to enhance the yields of the target end-product. In the present study, as reported in Table 1, succinic acid was not capable of competing with 1,3-PDO for reducing equivalents, due to its low yields. In addition, although lactic acid commonly achieved lower yields $(<0.09 \mathrm{~mol} / \mathrm{mol})$, it reached a yield of $0.14 \mathrm{~mol} / \mathrm{mol}$ at an initial glycerol concentration of $92 \mathrm{~g} / \mathrm{L}$. A study by Maina et al. [6] also reported that C. freundii VK-19 was capable of producing lactic acid as high as $21.7 \mathrm{~g} / \mathrm{L}$, yielding $0.17 \mathrm{~mol} / \mathrm{mol}$. Furthermore, similar to the present study, succinic acid productions were reported to be negligible $(<0.04 \mathrm{~mol} / \mathrm{mol})$. In another study by mixed cultures of Clostridia and Enterobacteria, considerable amounts of lactic acid production were observed during glycerol fermentation [28]. These results in the literature were in agreement with our study where increasing OLR up to a specific concentration $(62.5 \mathrm{~g} / \mathrm{L})$ increased the 1,3-PDO yields and then decreased the yields due to the possible undesirable presence of inhibitory substances in the raw substrate. These results suggest that lactic acid production should also be minimized to enhance overall yields of 1,3-PDO or 2,3-BD.

One of the main challenges of the utilization of crude glycerol is the choice of microorganisms due to the inhibitory components of the raw substrate [28]. The growth associated production of all products reported in Fig. 1 requires a primary metabolism. In this context, utilizing tolerant species or improving the cell yields are of great importance for higher concentrations of end-products. As shown in Table 2, the 1,3-PDO productivities were significantly improved with the employment of immobilized and continuous systems $[9,37]$. Compared with the previously reported literature by $\mathrm{C}$. freundii, the highest molar yield was achieved in the present study.

Table 2. Comparison of the operating conditions, 1,3-PDO yields and productivities in various studies using crude or pure glycerol.

\begin{tabular}{|c|c|c|c|c|c|c|}
\hline $\begin{array}{l}\text { Reactor } \\
\text { Type* }\end{array}$ & $\begin{array}{l}\text { Glycerol } \\
(\mathrm{g} / \mathrm{L}) * *\end{array}$ & $\begin{array}{c}\text { Mode of } \\
\text { action }\end{array}$ & $\begin{array}{c}\text { Inoculated } \\
\text { Microorganisms }\end{array}$ & $\begin{array}{c}1,3-P D O \\
\text { Yield } \\
\text { (moll } \\
\text { moll } \\
\end{array}$ & $\begin{array}{c}\text { 1,3-PDO } \\
\text { Productivity } \\
\text { (g/L.h) }\end{array}$ & Reference \\
\hline CSTR & $25 P G$ & Batch & $\begin{array}{c}\text { Klebsiella } \\
\text { pneumonia } \\
\text { CGMCC } \\
1.6366\end{array}$ & 0.52 & 1.65 & [38] \\
\hline CSTR & $\begin{array}{c}20-80 \\
C G\end{array}$ & Fed-batch & $\begin{array}{l}\text { C. butyricum } \\
\text { VPI } 1718\end{array}$ & 0.67 & 0.78 & [39] \\
\hline$P B R$ & $\begin{array}{l}40 C G \\
40 \mathrm{GlU}\end{array}$ & Continuous & $\begin{array}{l}\text { L. brevis } \\
\text { N1Eg.3.3 } \\
\text { C. freundii }\end{array}$ & 0.53 & 0.49 & [9] \\
\hline CSTR & $\begin{array}{c}40-170 \\
C G\end{array}$ & Fed-batch & $\begin{array}{c}\text { FMCC-B } 294 \\
(V K-19)\end{array}$ & 0.40 & 0.79 & [5] \\
\hline CSTR & $\begin{array}{c}15-50 \\
P G\end{array}$ & Batch & $\begin{array}{l}\text { C. freundii } \\
\text { AD119 }\end{array}$ & 0.72 & 0.96 & [2] \\
\hline$P B R$ & $36.8 P G$ & Continuous & $\begin{array}{l}\text { C. freundii } \\
\text { DSM } 30040\end{array}$ & 0.57 & 8.2 & [37] \\
\hline $\begin{array}{l}\text { Shaked } \\
\text { cultures }\end{array}$ & $\begin{array}{l}50 C G \\
1.5 \mathrm{Glu}\end{array}$ & Batch & C. freundii & 0.69 & - & {$[40]$} \\
\hline$M C P R$ & $\begin{array}{c}11-144 \\
C G\end{array}$ & Continuous & $\begin{array}{l}\text { C. freundii } \\
\text { DSM } 15979\end{array}$ & 0.78 & 2.47 & This study \\
\hline
\end{tabular}

*CSTR: Continuous stirred tank reactor; PBR: Packed bed reactor; MCPR: Modified continous biofilm reactor

**PG: Pure Glycerol, CG: Crude Glycerol, Glu: Glucose

\section{CONCLUSION}

An adequate approach to enhance the valorization of glycerol into several value-added products was performed with the aid of a modified continuous biofilm reactor (MCBR). This study depicted a novel approach to obtain the multi end-products including 1,3-PDO, 2,3-BD and acetic acid out of crude glycerol in a continuous mode of operation. The glycerol removal was realized between 20 to $100 \%$. 1,3-PDO was obtained in the highest yield of $0.78 \mathrm{~mol} / \mathrm{mol}$. The continuous MCBR showed good stability under elevating crude glycerol concentrations showing its feasibility to high OLR. The outcomes of this study may be used as a know-how to scale-up the process in non-sterile conditions for integrated systems to industrial scale biodiesel plants. Furthermore, the production of the valuable biomonomer 1,3-PDO, which has a very important place in the textile sector, can be a very profitable return to the manufacturer.

\section{ACKNOWLEDGEMENT}

The author would like to acknowledge Prof. Dr. Nuri Azbar for his insightful discussions. The author would like to acknowledge Prof. Dr. Fabio Fava and Assoc. Prof. Dr. Lorenzo Bertin for their valuable contributions and for providing the 
laboratory infrastructure. The author would like to thank Dr. Selene Grilli for her technical assistance with HPLC analysis.

\section{References}

1. Kumar V, Durgapal M, Sankaranarayanan M, Somasundar A, Rathnasingh $C$, Song $H H$, Seung D, Park S. Effects of mutation of 2,3-butanediol formation pathway on glycerol metabolism and 1,3-propanediol production by Klebsiella pneumoniae J2B. Bioresour Technol (2016) 214 432-440.

2. Drozdzynska A, Pawlicka J, Kubiak P, Kosmider A, Pranke D, Olejnik- Schmidt A, Czacyk K. Conversion of glycerol to 1,3-propanediol by Citrobacter freundii and Hafnia alvei newly isolated strains from the Enterobacteriaceae. N Biotechnol (2014) 31 402-410.

3. Boenigk R, Bowien S, Gottschalk G. Fermentation of glycerol to 1,3-propanediol in continuous cultures of Citrobacter freundii. Appl Microbiol Biotechnol 1993; 38: 453-457.

4. Homann T, Tag C, Biebl H, et al. Fermentation of glycerol to 1,3-propanediol by Klebsiella and Citrobacter strains. App Microbiol Biotechnol (1990) 33 121-126.

5. Metsoviti $M$, Zeng AP, Koutinas AA, Papanikolau S. Enhanced 1,3-propanediol production by a newly isolated Citrobacter freundii strain cultivated on biodiesel-derived waste glycerol through sterile and non-sterile bioprocesses. J Biotechnol (2013) 163 408-418.

6. Maina S, Kachrimanidou V, Ladakis D, Papanikolau S, Machado de Castro A, Koutinas A. Evaluation of 1,3-propanediol production by two Citrobacter freundii strains using crude glycerol and soybean cake hydrolysate. Environ Sci Pollut Res (2019) 26 35523-35532.

7. Casali S, Gungormusler M, Bertin L, Fava F, Azbar N Development of a biofilm technology for the production of 1,3-propanediol (1,3-PDO) from crude glycerol. Biochem Eng J. (2012) 64 84-90.

8. da Silva GP, Mack M, Contiero J. Glycerol: A promising and abundant carbon source for industrial microbiology. Biotechnol Adv (2009) 27 30-39.

9. Vivek N, Aswathi T V., Sven PR, Pandey A, Binod P. Selfcycling fermentation for 1,3-propanediol production: Comparative evaluation of metabolite flux in cell recycling, simple batch and continuous processes using Lactobacillus brevis N1E9.3.3 strain. J Biotechnol (2017) 259 110-119.

10. Pflügl S, Marx H, Mattanovich D, Sauer M. 1,3-Propanediol production from glycerol with Lactobacillus diolivorans. Bioresour Technol (2012) 119 133-140.

11. Zabed HM, Zhang Y, Guo Q, Yun J, Yang M, Zhang G, Qi $X$. Co-biosynthesis of 3-hydroxypropionic acid and 1,3-propanediol by a newly isolated Lactobacillus reuteri strain during whole cell biotransformation of glycerol. J Clean Prod (2019) 226 432-442.

12. Yun J, Yang $M$, Magocha TA, Zhang $H$, Xue $Y$, Zhang G, Qi X. Production of 1,3-propanediol using a novel 1,3-propanediol dehydrogenase from isolated Clostridium butyricum and co-biotransformation of whole cells. Bioresour Technol (2018) 247 838-843.

13. Guo Y, Dai L, Xin B, Tao F, Tang $H$, Shen $Y, X u$ P. 1,3-Propanediol production by a newly isolated strain, Clostridium perfringens GYL. Bioresour Technol (2017) 233
406-412.

14. González-Pajuelo M, Meynial-Salles I, Mendes F, Andrade JC, Vasconcelos I, Soucaille P. Metabolic engineering of Clostridium acetobutylicum for the industrial production of 1,3-propanediol from glycerol. Metab Eng (2005) 7 329336.

15. Gallazzi A, Branska B, Marinelli F, Patakova P. Continuous production of $n$-butanol by Clostridium pasteurianum DSM 525 using suspended and surface-immobilized cells. J Biotechnol (2015) 216 29-35.

16. Sanguanchaipaiwong V, Leksawasdi N. Using Glycerol as a Sole Carbon Source for Clostridium beijerinckii Fermentation. Energy Procedia (2017) 138 1105-1109.

17. da Silva Ruy AD, de Brito Alves RM, Reis Hewer TL, de Aguiar Pontes D, Teixeira Gomes LS, Pontes Magalhaes LA. Catalysts for glycerol hydrogenolysis to 1,3-propanediol: A review of chemical routes and market. Catal Today (2020) 0-1 DOI: 10.1016/j.cattod.2020.06.035

18. Ji XJ, Huang $\mathrm{H}$, Ouyang PK. Microbial 2,3-butanediol production: A state-of-the-art review. Biotechnol Adv (2011) 29 351-364.

19. Kalck P, Le Berre C, Serp P. Recent advances in the methanol carbonylation reaction into acetic acid. Coord Chem Rev (2020) 402213078.

20. Sun YQ, Shen JT, Yan L, Zhou JJ, Jiang LL, Chen Y, Yuan $\mathrm{JL}$, Feng EM, Xiu ZL. Advances in bioconversion of glycerol to 1,3-propanediol: Prospects and challenges. Process Biochem (2018) 71 134-146.

21. Białas W, Pikuła M, Mroczyk K, Grajek W. Production of 1,3-propanediol from glycerol by $\mathrm{C}$. butyricum: Optimization of medium composition and kinetic studies. N Biotechnol. (2014) S101 DOI: 10.1016/j.nbt.2014.05.1855.

22. Varrone C, Skiadas I V., Gavala HN. Effect of hydraulic retention time on the modelling and optimization of joint 1,3 PDO and BuA production from $2 \mathrm{G}$ glycerol in a chemostat process. Chem Eng J. (2018) 347 1525-534.

23. Yang X, Choi HS, Lee JH, Lee SK, Han SO, Park C, Kim SW. Improved production of 1,3-propanediol from biodieselderived crude glycerol by Klebsiella pneumoniae in fedbatch fermentation. Chem Eng J. (2018) 349 25-36.

24. Wischral D, Zhang J, Cheng C, Lin M, Galotti de Souza LM, Pellegrini Pessoa FL, Pereira Jr N, Yang ST. Production of 1,3-propanediol by Clostridium beijerinckii DSM 791 from crude glycerol and corn steep liquor: Process optimization and metabolic engineering. Bioresour Technol. (2016) 212 100-110.

25. Qureshi N, Annous BA, Ezeji TC, Karcher P, Maddox IS. Biofilm reactors for industrial bioconversion process: Employing potential of enhanced reaction rates. Microb Cell Fact (2005) 4 1-21.

26. Nemati M, Webb C. Immobilized Cell Bioreactors. Second Edi. Elsevier B.V. (2011) 331-346.

27. Paranhos AG de O, Silva EL. Statistical optimization of $\mathrm{H} 2$, 1,3-propanediol and propionic acid production from crude glycerol using an anaerobic fluidized bed reactor: Interaction effects of substrate concentration and hydraulic retention time. Biomass and Bioenergy (2020) 138105575.

28. Sittijunda S, Reungsang A. Fermentation of hydrogen, 1,3-propanediol and ethanol from glycerol as affected by organic loading rate using up-flow anaerobic sludge blanket (UASB) reactor. Int J Hydrogen Energy (2017) 42 2755827569. 
29. Chen H, Fang B, Hu Z. Simultaneous HPLC determination of four key metabolites in the metabolic pathway for production of 1,3-propanediol from glycerol. Chromatographia. (2007) $659629-632$.

30. APHA. Standard Methods for the Examination of Water and Wastewater, AWWA, WPCF. 19th ed. Washington, DC, USA: American Public Health Association (1995).

31. Yoneda Y, Yoshida T, Kawaichi S, Daifuku T, Takabe K, Sako Y. Carboxydothermus pertinax sp. nov., a thermophilic, hydrogenogenic, Fe(III)-reducing, sulfur-reducing carboxydotrophic bacterium from an acidic hot spring. Int $\mathrm{J}$ Syst Evol Microbiol (2012) 62 1692-1697.

32. Szymanowska-Powałowska D, Leja K. An increasing of the efficiency of microbiological synthesis of 1,3-propanediol from crude glycerol by the concentration of biomass. Electron J Biotechnol (2014) 17 72-78.

33. Aquino de Souza E, Rossi DM, Záchia Ayub MAÔ. Bioconversion of residual glycerol from biodiesel synthesis into 1,3-propanediol using immobilized cells of Klebsiella pneumoniae BLh-1. Renew Energy (2014) 72 253-257.

34. Wong CL, Huang CC, Chen WM, Chang JS. Converting crude glycerol to 1,3-propandiol using resting and immobilized Klebsiella sp. HE-2 cells. Biochem Eng J (2011) 58-59 177183.

35. Yang X, Kim DS, Choi HS, Kim KC, Thapa LP, Park C, Kim
SW. Repeated batch production of 1,3-propanediol from biodiesel derived waste glycerol by Klebsiella pneumoniae. Chem Eng J (2017) 314 660-669.

36. Zeng AP, Biebl H, Schlieker H, Deckwer WD. Pathway analysis of glycerol fermentation by Klebsiella pneumoniae: Regulation of reducing equivalent balance and product formation. Enzyme Microb Technol (1993) 15 770-779.

37. Pflugmacher U, Gottschalk G. Development of an immobilized cell reactor for the production of 1,3-propanediol by Citrobacter freundii. Appl Microbiol Biotechnol (1994) 41 313-316.

38. Zheng Z ming, Guo N ni, Hao J, Cheng KK, Sun Y, Liu DH. Scale-up of micro-aerobic 1,3-propanediol production with Klebsiella pneumonia CGMCC 1.6366. Process Biochem (2009) 44 944-948.

39. Chatzifragkou A, Papanikolaou S, Dietz D, Douelgeraki Al, Nychas GJE, Zeng AP. Production of 1,3-propanediol by Clostridium butyricum growing on biodiesel-derived crude glycerol through a non-sterilized fermentation process. Appl Microbiol Biotechnol (2011) 91 101-112.

40. Anand P, Saxena RK. A comparative study of solventassisted pretreatment of biodiesel derived crude glycerol on growth and 1,3-propanediol production from Citrobacter freundii. N Biotechnol (2012) 29 199-205. 